\title{
Resurgent Triads? Democratic mobilization and organized crime in Hong Kong
}

\section{Abstract:}

On 3 October 2014, peaceful pro-democracy protestors were attacked by thugs in Mong Kok, a working-class neighbourhood of Hong Kong. Using this event, we explore whether the attackers came from the same neighbourhood and mobilized to protect their illegal business activities, and whether the attackers were affiliated to the Triads. We conclude that the attackers were low-level Triads affiliates from outside Mong Kok and were paid to attack the protesters. While several scholars have suggested that Triads are in inexorable decline in post-1997 Hong Kong, we suggest that they might have found a new role as enforcer of unpopular policies and repression of democratic protests in the context of a drift towards authoritarianism in Hong Kong. The paper is based on field interviews with Triad members, businesspeople and activists, and on press reports and official documents.

Keywords: Thugs-for-hire; Mafias; Hong Kong Triads; Umbrella Movement; China 


\section{Introduction}

At the end of September 2014, thousands of citizens in Hong Kong took to the streets to demand universal suffrage. They objected to a decision taken by the Chinese government to retain veto power over who was allowed to stand for the post of Chief Executive (i.e., President) of Hong Kong. When a few activists decided to enter Civic Square in close proximity to the government headquarters, the police used tear gas to remove the crowd mainly university students - and arrested them. The excessive use of force outraged the population of Hong Kong and became instant news around the world. This was the match that sparked the Umbrella Movement (UM) a most extraordinary peaceful occupation of three sites in Hong Kong for over two months (September 28 - December 15, 2014) in the financial district of the city and in the working-class neighbourhood of Mong Kok (below, we use UM as an equivalent to 'Umbrella Movement,' 'Occupy Movement' and 'Occupy Central').

While peacefulness and disciplined, the occupation took an eventful turn on 3 October 2014 when the pro-democracy camp became the victim of an organized assault in the protest sites of Mong Kok. The events which unfolded on that evening constitute the contextual background of this study. The violence lasted all day, but the attack was eventually repelled. The New Yorker Magazine report on the event, entitled 'The Thugs of Mainland China' (Lim, 2014), suggested that the Chinese government had paid thugs to disrupt the peaceful protest. This is a practice that is common in China, as documented by Ong (2015). An alternative theory also suggested by early observers is that organized criminals acted on their own initiative to protect business interests from being disrupted in Mong Kok, where the Hong Kong Triads organize the local sex industry, impose protection payments on local businesses and control the minibuses (Tweed, 2014). Right from the beginning then two key questions had been posed: were the attackers locally based or were they coming from the outside? And were the attackers affiliated to the Triads or not? Scholars have shown that thugs-for-hire tend to come from outside the area being attacked and are not normally members of structured Mafia groups.

The events of October 2014 raise more general theoretical questions. First, what are the differences between the two types of privatized violence: the 'thugs-for-hire' phenomenon and Mafias? Second, the events of 3 October speak to the broader question of the relationship 
between democracy and organized crime, and the future of the Triads in Hong Kong. The paper first presents an ideal-type distinction between 'thugs-for-hire' and Mafiosi. We then consider the events of 3 October in the context of Hong Kong-China relationship. We conclude that the events of 3 October are further evidence that Triads in Hong Kong are behaving as thugs-for-hire. While several attackers were indeed members of the Triads, they hailed from outside the neighbourhood and did not mobilize to protect local businesses, as a traditional Mafia would do. Indeed, some local Triads opposed the attack as they perceived it as an encroachment of their territory. These events suggest that there is a tension within the Triads. We suggest that, in the context of greater control of the Beijing government over the affairs of the former British colony, organized crime will increasingly become an instrument to enforce unpopular policies or repress social protests. Hence the decline in the Triads noted by several scholars (e.g., Zhang and Chin, 2003; Lee, Broadhurst and Beh 2006; Broadhurst and Lee. 2009), maybe be reversed. We draw upon a set of interviews with key witnesses, official documents and press reports.

\section{Thugs-for-hire vs Mafiosi}

Thugs-for-hire are non-state actors used by authorities to impose policies and decisions upon a reluctant population. The thugs are 'agents' of the authorities and their allies, albeit the relationship with the 'principal' is informal and kept hidden. This type of privatized state violence allows officials to distance themselves from acts that are illegal and immoral in the eyes of the international community and higher authorities (Ong 2015:3). Thugs-for-hire differ from paramilitaries and militias as they lack a permanent organizational structure and are mostly drawn from the criminal underworld, where they return once the job is done. They are a form of covert intervention used by officials in contexts that are not plagued by civil wars, where instead we expect to find militias and paramilitaries, as in the case of Rwanda's genocide (see, e.g., Roessler 2005: 209).

Thugs-for-hire exist (or have existed) in a variety of contexts, such as Colombia (Sanford 2003), Philippines (Rommel 2010), Côte d'Ivoire (Mehler 2007:205), Nigeria (Smith 2007), Zimbabwe (Laurie 2011) and Kenya (van Stapele 2015). While the economic development of these countries ranges from high to relatively low, the political system is autocratic or only nominally democratic, yet captured by powerful small oligarchies, and the level of corruption is consistently high. For instance, during the authoritarian regime led by Suharto between 1965 and 1998, the military orchestrated anti-communist pogroms, killing between half a 
million to one million people. The perpetrators of the violence were individuals loosely connected to youth gangs encouraged by the army. The regime could plausibly deny involvement, while still being able to carry out its policy of annihilation of the communist opposition (Rickefs 2001:347). Thugs-for-hire were also used to repress the American labour movement at the end of the $19^{\text {th }}$ century (Adamic [1931] 2008).

Thugs-for-hire are a prominent feature of contemporary Egypt under the rule of General elSisi. A recent study of the continuing rise of the Egyptian 'securocratic' state describes the role of thugs-for-hire (Baltagya) as follows:

To support the needs of an ever-expanding regime of terror, the MOI [Ministry of Interior] started to 'outsource' its most 'dirty' business. With increasing impunity criminal investigation officers began to promote a new 'police force' of baltagya (thugs). Baltagya are criminals with a record of violence, who are paid to carry out duties of 'disciplining' members of the public in return for the police turning a blind eye to their criminal activities, including drug trafficking. The baltagya's job description has expanded to include voter intimidation, beating up, raping and sexually abusing criminal suspects and political activists, breaking up demonstrations, forcibly removing farmers from their land and much more (Abdelrahman 2016:5-6).

The phenomenon is significant in mainland China, as documented in a recent study by Ong (2015; see also Wang, 2014). Criminals are hired to repress citizens and coerce them into complying with unpopular policies and decisions. They are mostly recruited to enforce illegal housing demolitions and evictions, land expropriations, collection of taxes and illegal fees (Ong 2015:7). Occasionally, these ruffians wear a uniform, although they have no official pass, and are part of 'demolition squads' led by officials or real estate developers (Ong 2015:9). Local governments, facing tight deadlines and citizens' resistance, rely on thugs to expedite their projects and extract formal consent from communities. A researcher at the Chinese Academy of Science estimated that $90 \%$ of all demolition and relocation cases involved thug violence (cited in Ong 2015:8). Officials also employ violent individuals to harass petitioners and activists who challenge authorities. Usually, those hired are unemployed youngsters, with no specific skills, who ransack stores, tear down billboards, set houses on fire, loot, use intimidating language, and so on. Those recruited are invariably 
outsiders. As noted by Ong, 'Outsiders [...] have the advantage of not being recognizable to the locals or the subjects under attack' (Ong 2015:10).

While thugs-for-hire are able to use violence, they do not control a specific area. On the other hand, Mafiosi are in the business of governing a clearly defined and usually small territory (Varese 2010). They belong to rather complex and long-standing organizations that attempt to monopolize protection in a given space or market (Gambetta 1993). Mafias are composed of individual families sharing rules, admission rituals, a code of behaviour and a world view. Mafias have also developed ways to coordinate their activities and created forums to meet and discuss matters of common interest, while retaining a degree of independence from each other. While thugs-for-hire are invariably on the side of the ruling authorities (or businesspeople closely connected to the local authorities), Mafias are entities autonomous from the State and in principle opposed to it: they can side with opposition parties and even with individuals attempting a coup d'état.

Throughout their history, Mafias have supported politicians by intimidating voters and deploying violence in order to further the interests of local elites and state officials (Cockayne 2016). Yet they occasionally supported workers against employers, as long as they would get a tangible advantage. Gambetta (1993:92-93) writes that "a few renowned Mafiosi [...] acted on behalf of the peasants at one point or another in their careers and gained considerable fame as a result". Similarly, the Japanese Yakuza has offered services to the both centrist and rightwing politicians and the state (Siniawer 2008), but entertained relationships and helped leftwing activists (Miyazaki 2005:31-32, 55-56). In the 1990s, prominent crime figures in Russia consorted with centrist politicians, such as Boris Yeltsin, as well as nationalist, former communist and anti-communist parties (Varese 2001:182-183; Varese 2016). Mafias do not merely act as the State's hired hands.

Below, we explore two questions: First, where did the attackers of 3 October come from? Theoretically we would expect that Thugs-for-hire had come from outside the area of the protest, while Mafia members would come from Mong Kok itself. Second, we ask whether Triads self-mobilized to protect their business interest or were paid by others to do so. We conclude that Triads were paid to attack the protestors and did not self-mobilize. We suggest that the increasing importance of China in Hong Kong affairs is leading local organized crime to lose autonomy and become thugs-for-hire to harass protesters and impose unpopular policies. 
The paper proceeds as follows. Section 2 introduces the Triads in Hong Kong, while Section 3 discusses the evidence we have collected. Section 4 is a detailed reconstruction of the events of 3 October. Section 5 discusses the evidence. Section 6 concludes.

\section{The Hong Kong Triads}

Triads started their life as political organizations in mainland China, where they organized rebellions against the Qing dynasty, such as the 1844 Hakka Triad revolt in Waichow district in Guangdong province, and the Taiping Rebellion (1850-64). Even Sun Yat-Sen (18661925), the first President of the Republic of China, joined a Triad society and moved to Hong Kong to organize the republican movement, as did many other activists. Hong Kong had become, after the British arrival in 1842, the gateway for two international trades originating from South China: opium trafficking and slave labour. The boarding houses where the socalled 'coolies' stayed prior to shipment overseas were controlled by people who had joined the Triads in China; they were often ethnically based (i.e., people from a given province or district would stay together). When boarding-house owners tried to impose a monopoly over the labour market, conflict erupted. Eventually, several coolie houses adopted Triad rituals, becoming Mafia-type organizations. Amid the proliferation of Triads, some flourished and others disappeared. By 1909, when it must have been clear which ones had managed to survive, a meeting was held to stabilize the rituals and form an inter-group forum of Triad societies. This led to the formation of first Triad association, the Wo (Chu 2000:18). The process of 'Triadization' continued throughout the $20^{\text {th }}$ century, with professional associations and trade unions adopting Triad rituals. As time passed, Triads started to offer protection to those operating in their spheres of influence (Chu 2000:21). Triad organizations such as Wo Shing Wo, 14K and Sun Yee On, continue to be active today (Chu, 2000; Chin, 1990; Lo, 2010; Wang and Antonopoulos, 2015). In 2013, 2,035 Triad-related crimes were reported, with 2,844 people arrested (HKG Yearbook 2013:260; Tweed, 2014). In a ten-year period (1989-1998), 95 out of 804 homicide events have been identified as Triad related homicide cases (Lee, Broadhurst and Beh 2006).

Until the 1980s, Triad societies displayed a degree of autonomy and were even a potential threat to the Communist China. In the aftermath of the Tiananmen massacre, as the Chinese authorities were pursuing the leaders of the student protests, members of the Sun Yee On Triad - which had contacts in Hong Kong's harbour ports-- arranged for at least 150 people to escape from the mainland to Hong Kong by speedboats, at the time a British territory, and 
then to France and the United States, in an operation known as Operation Yellowbird (Lo 2010: 8-9; Feng, 2009). Preparing for the island handover to China in 1997, the Beijing government was worried that Triads societies, and in particular the most powerful Sun Yee On Triad, would side with liberal political activists and destabilize post-1997 Hong Kong (Lo 2010:9). Hence a deliberate strategy to woo the Triads into the pro-Beijing camp was started. The strategy to incorporate Triads into the anti-democratic camp included official statements of support for 'patriotic Triads' and granting business opportunities to Triads leaders in China, in exchange for their support in Hong Kong (SCMP 1997). On 8 April 1993, China's then-minister of public security, Tao Siju, stated that China was willing to work with Triads if they were "patriotic and concerned with the stability and prosperity of Hong Kong" (Dobson, 1993). Members of Sun Yee On also met with Tao Siju in Beijing (Dobson, 1993).

From the early 1990s, China opened its doors to several Triad societies' investments. In May 1992 a boss of Hong Kong 14K Triad group, Huang Jianming, entered China and started a program of investments of $14 \mathrm{~K}$ funds into Shenzhen, beginning with a restaurant. By 1998, he had acquired thirty-five properties. A nightclub co-owned by Charles Heung- the son of the Sun Yee On founder - and the minister of public security was opened in Beijing a few days before Tao's statement (Lintner 2004:91). In August 1993 the vice chairman of one of China's highest political bodies opened a film production centre in China owned by two Sun Yee On leaders, Charles and Jimmy Heung (Lo 2010:8) The Sun Yee On also invested in a multiplex to be built in Nanshan. Nuoquan Chen, a former high-ranking member of the Wo Shing Tong Triad society, bought a hotel in Shenzhen (his hometown), where he recruited local youngsters and formed his own gang, the Flying Eagle. According to an investigation conducted in Shenzhen in 1999, among the fifty-two restaurants and entertainment businesses owned by overseas citizens, thirty-two were associated with outside Triads, making up 62 percent of the total (He 2002:139-40; Chu 2000:132).Lo (2010) documents that the leaders of the Sun Yee On converted the capital they made in China through illegal means in the Hong Kong stock market.

The events described above suggest a transformation in the nature of the Triads, from a rather well organized and coordinated set of criminal groups all subscribing to the same rules and rituals, to a more disorganized entities, with low level of internal cohesion, projected towards exploiting business opportunities in China rather than enforcing territorial control (Lintner 2004:94: Lo 2010:2 and 15). As noted by Lee, Broadhurst and Beh (2006:183), contemporary Triads in Hong Kong are "less and less distinguishable from other youth and street gangs". At 
the same time, such groups still maintain the ability to use violence against dissenters. In February 2014, a critic of the Communist Party and former editor of the outspoken Hong Kong newspaper, Ming Pao, Kevin Lau, was brutally attacked with a cleaver. It has been alleged that the attack had been carried out by the Shui Fong Triad (Mullany, 2014; Levin, 2014).

We now turn to the Umbrella Movement (UM) and the events of 3 October 2014. Below we present the data we collected.

\section{Data Collection}

The paper is based on extensive field observations, interviews with informants, and a systematic review of relevant newspaper reports. Issues of representation, validity and reliability are particularly salient for those who study organised crime. The authors are fully aware of these issues and have done the following to overcome these issues in their process of data collection.

Author 2 is from Hong Kong and has visited the UM sites since the beginning of the protests frequently (averaging $4-6$ times a week). Author 1 has also visited Hong Kong during the occupation of Mong Kok. Purposive sampling yet additional criteria were adopted in order to filter out unreliable data. During the period of UM, there were speculations as the events unfolded. In order to increase the reliability of the data in the paper, we only interviewed individuals who fit one of the following criteria: (1) they were present in Mong Kok at the night of the attack; and/or (2) they had first-hand knowledge of the events; and/or (3) they were based in Mong Kok.

There were two main ways to establish the interviewee pool under the criteria set. While it is particularly difficult to access individuals directly involved in organized crime, the authors were introduced to two respondents connected to the Triads because they had direct knowledge of the neighbourhood and the events related to 3 October. One of our respondents, named Shek in the paper, joined the Triads as a teenager and has been active in Yau Ma Tei and Mong Kok (both in the Kowloon section of Hong Kong). He has now left active criminality and manages several bars in Causeway Bay and Wanchai. Shek revealed that he knew of the attacks before the evening on October $3^{\text {rd }}$ and was in Taipei when the attacks took place. A second source of the paper drawn from the world of the Triads is 
'Brick Brother' (also a fake name), a senior rank triad member active in Kowloon West. Author 2 has conducted extensive conversations with both sources.

Further, we interviewed activists and pro-democracy protestors, news reporters, barristers and solicitors representing the arrested protestors, volunteers at the First Aid Station and academics who were present on the night of the events. A small number of the interviewees were referred to by personal contacts of the authors (including representatives of local minibus trade union and taxi operators / owners) and they were interviewed after the attacks in Mong Kok. Author 2 also attended a number of political discussion groups after the attacks and identified a number of interviewees and conducted interviews with them.

During the period of the UM, there was a significant amount of speculative reporting of causes of events that have happened or predictions of how events will unfold. To safeguard the reliability of our sources of media reports, the authors conducted a systematic review of the newspaper articles published both in Chinese and English on the events, and draw selectively upon them. The authors used a mixture of Western and reputable Chineselanguage sources.

\section{The Umbrella Movement (UM) and the events of 3 October}

During the UM, protestors occupied three areas of Hong Kong - Admiralty, Causeway Bay and Mong Kok - from 28 September to 15 December (See Figures 1 and 2).

[Figures 1 and 2 about here]

The key set of events that concern us here occurred on 3 October 2014, when an organized group of individuals attacked the UM camp in the working-class of Mong Kok, known to be a Triads stronghold. Below, we present a timeline of the events of that day. The main source is the South China Morning Post's detailed timeline entitled 'Occupy Central - Day Six: Full coverage of the day's events', published online on 3 October and updated in the following days (SCMP 2014a). We then supplement this information with interviews we conducted with people present that day and field observations. ${ }^{1}$

Around 10 am several men started to remove sandbag barriers at the protest site in Mong Kok, on the junction of Sai Yeung Choi Street South and Argyle Street (see Figure 2). By 
$2.10 \mathrm{pm}$, minor clashes had broken out between pro- and anti-UM protestors, with the latter removing tents and barriers, and getting into brawls. An hour later, an anti-Occupy group had managed to remove barriers and scuffled with protestors. Around $4.30 \mathrm{pm}$, police established a cordon around the sit-in at the junction of Argyle Street and Nathan Road, while antiOccupy activists were stopped by a chain of police officers as they charged at the cordon. Just before $5 \mathrm{pm}$, a student demonstrator collapsed and lost consciousness where a large group of anti-Occupy demonstrators had encircled the Occupy group. A TV reporter saw 'people [who] had face mask[s], they were not the usual faces you see in Mong Kok. I saw them attacking people and destroying tents' (News1). Supporter2 noticed that attackers "came out of nowhere ... the assault was clearly organized in advance and coordinated". The thin line of police separating opposing sides was stretched to breaking point, and finally gave way shortly after 5 pm. By 6 pm, the Mong Kok protest site had 'descended into violence,' according to SCMP (2014a; for Solicitor2, "the situation was completely out of control"). More pro-democracy supporters rushed there after work, although pro-democracy leaders had urged protestors to leave the scene for their own safety. The activists stayed put (Lee 2014).

While the crowd of anti-Occupy individuals was growing bigger than the original few hundred, police officers remained few and stretched. A senior News Editor of a local television told us that this was due to the decision of the Chief Executive, C. Y. Leung, to keep government offices open. In order to fulfil this order, officers had to be deployed in the Admiralty area (News2; see Figure 1). At this point, Occupy protestors were worried for their personal safety and did not understand why police reinforcements were not arriving. Mary, a volunteer at one of the Mong Kok medical supplies stations, said that the police were not protecting the students. Instead, they were watching by the side (FirstAid1). Barrister1 was shocked by the police's lack of intervention to protect protestors (cfr Lo 2016, who suggests that the police acted responsibly).

The confrontation between the two camps continued as one of the UM organizers, Benny Tai, at $9.10 \mathrm{pm}$, declared that he suspected Triads of being behind the attack. At 10.15 p.m., the police ordered demonstrators in Mong Kok to leave the site immediately, to no avail. By 10.35 p.m., fighting had again broken out, while the police failed to intervene. Instead, officers formed a line about 20 metres away from the fracas, watching from a distance while guarding the main occupied road junction. The two parties were eventually separated by bystanders. Police ignored repeated calls for officers to intervene. 
As the day was coming to an end, the police suggested that the UM supporters were to blame for the confrontation. Spokesman Kong Man-keung said police had repeatedly told the crowd to leave over the past few days. Asked why force was not used against violent counterprotestors, he said decisions were made by officers and inspectors on the ground. He denied allegations that the police had failed to act, adding that 'we swiftly deployed a lot of manpower to control the situation' when the incident happened. He said rumours of police letting criminals off the hook were groundless and that they had been monitoring the situation closely over the past few days (SCMP 2014a). No weapons were used by both sides but reports of sexual harassment; assaults and intimations were alleged to have taken place. Ultimately 12 people and 6 police officers were injured (Kaiman, 2014b).

As the anti-UM activists continued to attack pro-democracy supporters, and officers failed to intervene, Amnesty International condemned Hong Kong police for not protecting peaceful demonstrators. Around 3 a.m., activists had reclaimed a section of Argyle Street leading to the junction with Nathan Road near Langham Place, a shopping complex in Mong Kok behind the main occupation site. By 4.30 a.m., the situation had calmed down. The antiOccupy camp had retreated. By dawn, protestors had largely rebuilt the barricades and tents which had been destroyed. As the sun rose over Hong Kong on the morning of 4 October, around 200 pro-democracy students were at the crossroads of Nathan Road and Argyle Street to defend the site. The attack had failed.

During a press conference in the early hours of 4 October, authorities gave their account of the events of 3 October. Nineteen men had been arrested in clashes in Mong Kok on three charges, eight of whom were believed to have Triad backgrounds. They were facing different charges of unlawful assembly, fighting in a public place, and assault, said district commander Kwok Pak-chung. Although no weapons were used by the attackers, at least 12 people and six police officers had been wounded. Kwok did not rule out more arrests, stressing that the police had been fair and did not enforce the law selectively. The anti-UM attackers arrested on the night of 3 October were immediately released on bail and then cleared of all charges (Bloomberg 2014; Kong Tsung-gan 2015). To his knowledge, only pro-democratic activists are still being prosecuted (Barrister1). 


\section{Origins and Motivations of attackers}

Here, we address two issues: 1) From where did the attackers come? 2) Did Triads selfmobilize to protect their business interests, or were they paid by others to do so?

A key element of the thugs-for-hire argument is that attackers are drawn from rather distant areas, so that the locals would not recognize them.

A news reporter stationed in Mong Kok maintains that he had never seen the people involved in the confrontation until the night of the attack. He described them as 'people you would not want to be on the same side of the pavement with [...] You would cross the road if you see them just to get out of their way.' He picked up a rumour that anti-UM protestors were shuttled to Mong Kok by minibuses and vans. A social worker from a different part of town told him that 'some of the kids [the worker] was counselling told [the worker] that they were going to have some fun in Mong Kok because they were told to' (News1; Solicitor2, his office based in Mong Kok was told by his acquaintances in the neighbourhood that "the attackers were not from Mong Kok").

From where had those people come? In the early morning of 3 October, Triad 1 received a text message from his bosses and friends asking him to recruit people for the day, and received a second message to that effect in the evening, when the violence had already broken out and the anti-UM protestors needed reinforcement. He added some information on the profile of those who joined the fight:

Most of the people who went were youngsters aged between 15 to 20 something. They were nobody in their Triad group, so they saw this as an opportunity to prove their strength, to humiliate the police, and to impress their bosses whereas the older ones would want more money (Triad1).

He added that those who joined the fight were based in Hong Kong rather than on the mainland: 'There might have been people of Indian and Pakistani origins because the Sing Wo Triad recruits in these communities, but are based in Hong Kong,' he concluded (Triad1).

Brick Brother said regarding the events of 3 October:

I know the people who beat up the students on the $3^{\text {rd }}$ of October, I saw them on television [he mentions several names and laughs]. They received money 
from their bosses to disrupt the protests. The vast majority are based in Shum Shui Po [an area north of Mong Kok], where they oversee the electronics and wet markets. They went to disrupt the protests and to remove fences. Some came from the New Territories. They belong to the Shui Fong Gang, Wo Shing Wo and 14K Triads. I was not surprised that they were all released after being briefly arrested because the higher command of the police knew they were coming (Triad2).

Payments varied depending on experience and seniority. Low level hoodlums were paid 800 HK\$. More senior people got offered between HK\$1,500 to 3,000 for the day, while senior Triads were paid up to $\mathrm{Hk} \$ 10,000$ per day (Triad 1; Triad 2; Taxi1). ${ }^{2}$

When, after 3 October, Brick Brother saw some of the people who took part in the attacks, he asked them about the clashes and how much they were paid. Their reply was: 'Ai! Why we talk about this?' (Triad 2). Shek and Brick Brother were not the only Mafiosi to acknowledge the infiltration of Triads (the notion of a 'patriotic Triad' is discussed in the academic literature as well: see Lo 2010:864).

In conclusion, individuals, some with Triads background, received cash to attack the students, and the aggressors came from Hong Kong, rather than the mainland. Crucially, the attackers did not come from Mong Kok but other parts of Hong Kong, including the New Territories (an area bordering with China).

Several theories have been put forward as to why the Hong Kong Triads mobilized. One view is that Triads self-mobilized to protect their businesses in the area, in particular the sex trade, gambling venues, the minibus routes and the various shops that pay protection money to organized crime in Mong Kok. In such a scenario, the money paid to rank-and-file would come from the Triads coffers. Such a view was also reported in the media. For instance, Bloomberg ran a story entitled 'Triads See Underworld Business Hurt by Hong Kong Protests' (Bloomberg, 2014). Alternatively, Triads could have mobilized because they were asked to do so by individuals close to the centre of power, and could have been rewarded for their service. To put it differently, they acted as a thugs-for-hire. Below, we assess the available evidence.

The taxi drivers we spoke to were generally unhappy at the road disruption caused by the UM (e.g., Taxi1 and Taxi3). One of them suggested that the students should 'set fire to 
themselves to get attention and get it over and done with' (Taxi4). However, drivers admitted that they had not lost much money during the occupation. 'After all, trips were longer,' one pointed out (Taxi2). The owner of a 200-strong taxi company told us that although the loss was significant initially, revenues actually went up towards the mid- and the final phases of UM. He noted that people were more willing to take taxis to return home from Occupy sites in the evening (Taxi Operator1). A news reporter was told by drivers that they had not lost money, yet owners of taxi and minibus companies had lodged injunctions to remove the protestors as part of a politically motivated, anti-Occupy strategy (News1). ${ }^{3}$

One of the sectors allegedly suffering greatly was the private (red) minibuses, known to be controlled by Triads in Hong Kong. In order for the minibus drivers to pick up passengers, they have to pay a 'station fee' to the Triads controlling their stops (Chu 2000:56-58). During the UM, many minibuses had to change routes. ${ }^{4}$ The leader of a minibus trade union told us that the drivers were affected at first, but adjusted quickly and found alternative routes (Minibus TU). The respondent is a vocal opponent of UM and told us that some of his drivers did not even go to work because they would not earn much during the UM. ${ }^{5}$ Yet, he commented that the biggest loss of income was among drivers stationed on Hong Kong Island rather than at the Mong Kok Occupy site (Minibus TU).

Our interviewees connected to organized crime admitted that the loss of income was minimal. Prostitution and gambling close to the occupied areas in Mong Kok were at first affected, but revenue picked up quickly (Triad1 and Triad2). Shek pointed out that minibuses at first had to avoid the occupied areas and lost some money in the process because there were fewer passengers, but soon they were back in business using different routes protected by $14 \mathrm{~K}$, Sing Wo and Wo Sing Wo Triads (Triad1). Brick Brother added that 'the roads are open, why would business go down?' Brick Brother said that many drivers were re-assigned to New Territories during UM and none of them actually were out of work (Triad2).

Both Shek and Brick Brother dismissed the notion that Triads self-mobilized to protect their businesses. Triads' income is diverse, so even if organized crime lost some money from minibus revenues, it is not entirely reliant on one source, and would not launch such a high profile and costly attack (Triad1; Triad2). Brothels, pubs and gambling in Mong Kok lost a little revenue at the beginning of UM, but customers quickly returned, and the loss of profit was only temporary (Triad1; Triad2). Our informants pointed out that the protection fee is 
mandatory, and there is no such thing as a discount if business is bad; thus, the income from protection payments was not affected (Minibus TU; Triad1; Triad2).

Who paid the Mafia to intervene? A senior reporter from an independent news outlet who followed the events of the UM very closely told us that: 'the people that disrupted the protests were individuals from Hong Kong that wanted to please the central government and to make the statement that they are on China's side' (News2). This informant went on to explain who was behind the attack:

One has to look back at how developers managed to acquire land in the New Territories. According to the regulations, male indigenous inhabitants have the right to build a house on their plot of land. Developers were buying titles of ownership so local residents asked the government to hold consultation meetings. The tycoons hired Triads to disrupt these meetings and to put pressure on the government. The government turned a blind eye. The tycoons wanted to pay back the government and funded Triad gangs from the New Territories and Kowloon to intervene (News2).

For this informant, business interests in Hong Kong were behind the attack. This view is also confirmed by pro-UM academics we interviewed (Academic1; Academic2). Brick Brother suggests that the source was a Chinese state enterprise operating in Hong Kong and private donors in Hong Kong. They both thought that it was a 'good investment' to impress Beijing (Triad2). He would not speculate further.

Crucially, our informants maintain that the local Mong Kok gangs had not been asked permission for the attack. "Local gangs were not asked permission and were not happy to see such invasion," said News2. Triad1and Triad2 both confirmed this information. Since the attack failed, the police lost face and were angry. They warned the local Triads against allowing such an action to take place again undertaking such actions in their territory: 'Police said: "if you come out again, we will harass your brothels, bars and night clubs with daily inspections". So the Triads backed off.' (Triad1; News1 and News2). After this stark warning, local Triad members hung around the protestors' site in order to ensure that violence would not escalate again (Triad1). Indeed, no serious incident has been recorded since. 
In conclusion, Triads did not self-mobilize. Rather, they were paid to do so by business interests. We also found evidence suggesting a tension between local Triads, who run some illegal activities, and individuals attached to outside Triads who conducted the attack without asking permission.

\section{Conclusions}

Thugs-for-hire is an under-explored phenomenon entailing the use of state-sponsored violence to enforce unpopular policies upon a recalcitrant population, or to harass protestors and petitioners. It has been recorded in several contexts, and is particularly significant in China (Ong, 2015). How does this phenomenon differ from the Mafia? This paper has highlighted the ideal-typical differences between Mafias and thugs-for-hire. The latter are hired directly by authorities and, once the job is finished, return to being active in petty criminal activities. Mafias, on the other hand, attempt to control territories and markets, subscribe to a precise world view and code of honour, and each Mafia family coordinates with the families belonging to the same Mafia. Crucially, they are autonomous from State authorities.

This paper has shown that the attackers on 3 October 2014 belonged to the Hong Kong Triads. Although they had not been bussed from China, they hailed from different parts of Hong Kong and outside Mon Kok. Triad members mobilized because they were paid by powerful business interests connected to the Hong Kong government. We cannot rule out completely that these in turn were instructed by the Chinese government. We have documented that the loss in revenues suffered by businesses in the district of Mong Kok was not high enough to justify a direct intervention by organized crime.

Several scholars have documented over the past fifteen years a steady decline in role of Triads in illegal markets and as a featured tolerated by the public at large. Broadhurst and Lee (2009) have noted how anti-corruption efforts, improved enforcement, and the evolution of illegal markets have led to a decline in Triads as suppliers of illegal goods, and criminal protectors (see also Zhang and Chin 2003). The increasing mainland control over Hong Kong $(\mathrm{Wu}, 2015)$ is likely to have an effect over the Triads. As a regime becomes more authoritarian, we expect the room for manoeuvre for providers of alternative providers of 
order to be reduced, to the point of being zero under a Stalin or a Hitler. In such a regime, the authorities can harass protestors directly or use thugs. The evidence presented above suggests that the Hong Kong Triads might have found a new role, namely to become the preferred extra-legal vehicle to enforce unpopular policies and repress social movement. The current authoritarian trajectory in Hong Kong might well give Triads a new life line and purpose. 


\section{Interviews*}

Academic1 Professor of Social Sciences and supporter of UM, 06/11/2014.

Academic2 Professor of Social Sciences and Trade Union Activist,02/11/2014.

Academic3 Professor of Social Sciences present in Mong Kok on 3 October, 02/11/2014.

Business1 Nail Salon Owner, Mong Kok, 17/10/2014.

Barrister1 Randy Shek, Barrister who represents UM protesters, Hong Kong, 10/01/2017

Solicitor 1 Jonathan Man, Solicitor who represents UM protesters, Hong Kong, 04/01/2017

Solicitor2 Kenneth Lam, Solicitor who represents UM protesters and office based in Mong Kok, 12/01/2017

FirstAid1 Mary, volunteer at the Mong Kok First Aid Station, 18/03/2015.

Minibus1 Minibus Driver, Mong Kok, 15/10/2014.

Minibus TU Senior member of a trade union for minibus drivers, 27/07/15.

News1

News Reporter stationed in Mong Kok for the entire period of UM, $30 / 1 / 2015$.

News2

Senior News Editor, independent news outlet, 6/11/2014 and 17/12/2014.

Psychologist1 Representative of Hong Kong Psychologists Concern, supporter of UM, present in Mong Kok on October 3, 2014. 02/01/2017

Taxi1

Taxi Driver on Kowloon side, 8/10/2014.

Taxi2

Taxi driver, mid-November (night before the alleged clear up of MK), $15 / 11 / 2014$.

Taxi3

Taxi Driver, 17/10/2014.

Taxi4

Taxi Driver, 10/10/2014.

Taxi Operator1 Taxi Operator and owner of taxi company, also the owner of minibuses 27/08/15.

Triad1

Shek. He described himself having a Triad 'background.' Very active during the 1990s, he now manages a number of bars in Causeway Bay and Wanchai, 10/11/2014.

Triad2 Brick Brother, senior Triad Member. A senior rank triad in Wo Shing Wo group, 9/3/2015.

Supporter 1 Ben, Chinese University graduate present in Mong Kok on the night of the attacks, 18/03/2015. 
Supporter 2 Johnson Yeung, former V-Secretary of Hong Kong Federation of Students; Commander of Admiralty patrol team, 03/01/2017.

Supporter 3 Veteran Chinese pro-democracy activist, present in Mong Kok on 3 October 2014, Hong Kong, 17/01/2017

*Most names have been changed to protect the identities of the interviewees. Some interviewees did not request anonymity. 


\section{Newspaper Articles}

Barber, E. 2014. Hong Kong Student Protestors Prepare for Midterms and for Harder Questions. Time Magazine, 14 October 2014. Available at: http://time.com/3503870/occupy-central-hong-kong-student-protesters-midtermsexams-class-boycott-democracy/ [accessed 16 May 2016]

Bradsher, K. 2014. Hong Kong Government's Strategy on Protestors: Wait them Out. The New York Times, 1 October 2014. Available at: http://www.nytimes.com/2014/10/02/world/asia/hong-kong-protests.html? r=1 [accessed 16 May 2016]

Dobson, C. 1993. Hong Kong Triads Meet Top Chinese Minister. South China Morning Post, 11 April 2014. Available at: http://www.scmp.com/article/25568/hk-triads-meet-topchinese-minister [accessed 16 May 2016]

Kaiman, J. 2014a. Hong Kong Protestors Beaten and Bloodies as Thugs Attack Sit in. The Guardian, 4 October 2014. Available at: http://www.theguardian.com/world/2014/oct/03/hong-kong-protestesters-democracyoccupy [accessed 16 May 2016]

Lee, B. 2014. Hong Kong Protests 2014: Violence Erupts At Mong Kok Protest Site. International Business Times, 3 October 2014. Available at: http://www.ibtimes.com/hong-kong-protests-2014-violence-erupts-mong-kok-protestsite-1699062 [accessed 16 May 2016]

Levin, D. 2014. Triad Links to Attack on Protestors Raise Some Old Questions. International New York Times, 4 October 2014. Available at: http://sinosphere.blogs.nytimes.com/2014/10/04/triad-links-to-attack-on-protestersraise-some-old-questions/?_r=0 [accessed 16 May 2016]

Lim, L. 2014. The Thugs of Mainland China. The New Yorker, 8 October 2014. Available at: http://www.newyorker.com/news/news-desk/thugs-mainland-china-hong-kongprotests [accessed 16 May 2016]

Lo, C. 2010. Bus Drivers Milked for Millions by Triad, Police Say. South China Morning Post, March 23. Available at: http://www.scmp.com/article/709372/bus-driversmilked-millions-triad-police-say [accessed 16 May 2016]

Mackey, R. and P. Pan. 2014. Updates on Hong Kong Protests. International New York Times, 3 October 2014. Available at: http://news.blogs.nytimes.com/2014/10/03/liveupdates-from-hong-kong-protests/?_r=0 [accessed 16 May 2016] 
Mullany, G. 2014. Hong Kong Editor Whose Ouster Stirred Protests is Slashed. The New York Times, 25 February 2014. Available at:

http://sinosphere.blogs.nytimes.com/2014/02/25/hong-kong-editor-whose-ousterstirred-protests-is-reported-stabbed/? r=1\%20 [accessed 16 May 2016]

SCMP (South China Morning Post). 2014a. Occupy Central - Day Six: Full coverage of the day's events. South China Morning Post, 3-8 October 2014. Available at: http://www.scmp.com/news/hong-kong/article/1608680/live-student-protestors-awaitdialogue-date-lung-wo-road-open-traffic?page=all [accessed 16 May 2016]

SCMP (South China Morning Post). 2014b. A Battle for the Streets: Clashes between Occupy Activists and Opponents Intensify. 14 October 2014. Available at: http://www.scmp.com/news/hong-kong/article/1615919/battle-streetsadmiralty?page=all [accessed 16 May 2016]

Tweed, D. 2014. Triads See Underworld Business Hurt by Hong Kong Protests. Bloomberg, 10 October 2014. Available at: http://www.bloomberg.com/news/articles/2014-1009/hong-kong-s-triads-see-underworld-business-squeezed-by-protests [accessed 16 May 2016]

\section{References}

Abdelrahman. M. 2016. Policing neoliberalism in Egypt: the continuing rise of the 'securocratic' state. Third World Quarterly. DOI: 10.1080/01436597.2015.1133246.

Adamic, L. [1931] 2008. Dynamite: The Story of Class Violence in America. AK Press.

Banlaoi, R. C. 2010. 'The Sources of the Abu Sayyaf's Resilience in the Southern Philippines' CTC Sentinel 3(5): 17-19.

Broadhurst, R., and K.W. Lee. 2009. 'The Transformation of Triad 'Dark Societies' in Hong Kong: The Impact of Law Enforcement, Socio-Economic and Political Change' Security Challenges 5(4): 1-38.

Cai, Y. 2016. The Occupy Movement in Hong Kong: Sustaining Decentralized Protest. London: Routledge.

Chin, K.L. 1990. Chinese Subculture and Criminality: Non-Traditional Crime Groups in America. Greenwood Press.

Chu, Y. K. 2000. The Triads as Business. Routledge.

Chu, Y.K. 2005. Hong Kong triads after 1997. Trends in Organized Crime 8(3): 5-12. 
Cockayne, J. 2016. Hidden Power: The Strategic Logic of Organized Crime. New York: Oxford University Press.

Feng C. 2009. A Tiananmen Journal. Sun Chung Books.

Gambetta, D. 1993. The Sicilian Mafia: The Business of Private Protection. Harvard University Press.

He, B. 2002. Studies on mafias and mafia-related crimes in mainland China [in Chinese]. China Fazhi Press.

He, B. (ed.) 2003. Deciphering mafia related crimes [in Chinese]. China Procuratorial Press. HKG (Hong Kong Government). 2013. Hong Kong Yearbook. Available at: http://www.yearbook.gov.hk/2013/en/

Kong Tsung-gan. 2015. Overview of legal cases related to the HK Umbrella Revolution. Available at: https://medium.com/@KongTsungGan/overview-of-legal-cases-relatedto-the-hk-umbrella-revolution-7734adecdb0

Laurie, A.C. 2011. Political Violence in Zimbabwe's Land Seizure Era. DPhil Thesis, Oxford University.

Lee, K.W., Broadhurst, R.G. and Beh, P.S., 2006. Triad-related homicides in Hong Kong. Forensic Science International 162(1): 183-190.

Lintner B. 2004. Chinese Organized Crime. Global Crime 6:84-96.

Lo, S.S.H, 2016. 'Policing the Occupy Central Movement in Hong Kong', in S.S.H. Lo, The Politics of Policing in Greater China. New York: Palgrave Macmillan, pp. 169-194

Lo, T. W. 2010. Beyond Social Capital: Triad Organized Crime in Hong Kong and China. British Journal of Criminology 50 (5): 851-872.

Maruko Siniawer, E. 2008. Ruffians, Yakuza, Nationalists. The Violent Politics of Modern Japan 1860-1960. Cornell University Press.

Mehler, A. 2007. Political Parties and Violence in Africa: Systematic Reflections against Empirical Background. In M. Basedau, G. Erdmann and A. Mehler, eds., Votes, Money and Violence: Political Parties and Election in Sub-Saharan Africa, University of Kwazulu-Natal Press: 194-223.

Ng, J.Y. 2016. Umbrellas in Bloom: Hong Kong's Occupy Movement Uncovered. Blacksmith Books.

Ong, L. H. 2015. 'Thugs-for-Hire': State Coercion and Everyday Repression in China (May 25, 2015). Available at SSRN: $\underline{\text { http://ssrn.com/abstract=2609999 }}$ 
Rickefs, C. M. 2001. A History of Modern Indonesia since c. 1200. Stanford University Press.

Smith, D.J. 2007. Violent Vigilantism and the State in Nigeria. The Case of the Bakassi Boys. In Edna G. Bay and Donald L. Donham (eds.), States of Violence: Politics, Youth, and Memory in Contemporary Africa. University of Virginia Press: 127-147. van Stapele, N. 2015. Respectable 'Illegality': Gangs, Masculinities and Belonging in a Nairobi Ghetto. PhD Dissertation. University of Amsterdam.

Varese, F. 2001. The Russian Mafia. Private Protection in a New Market Economy. Oxford University Press.

Varese, F. 2010. What is Organized Crime? Introduction to F.V. (ed.), Organized Crime. Routledge: 1-35.

Victoria, S. 2003. Learning to Kill by Proxy: Colombian Paramilitaries and the Legacy of Central American Death Squads, Contras, and Civil Patrols. Social Justice 30 (3): 6381.

Wang, P. 2014. Extra-legal Protection in China. How Guanxi Distorts China's Legal System and Facilitates the Rise of Unlawful Protectors. British Journal of Criminology 54(5): 809-830.

Wang, P. and G.A. Antonopoulos. 2015. Organized crime and illegal gambling: How do illegal gambling enterprises respond to the challenges posed by their illegality in China? Australian \& New Zealand Journal of Criminology (2015): doi $10.1177 / 0004865815573874$.

Wu, C. H. 2015. Dance with the Dragon: Closer Economic Integration with China and Deteriorating Democracy and Rule of Law in Taiwan and Hong Kong? Hong Kong Law Journal. Forthcoming.

Zhang, S., \& Chin, K. L. (2003). 'The declining significance of triad societies in transnational illegal activities. A structural deficiency perspective.' British Journal of Criminology, 43(3): 469-488. 


\section{ENDNOTES:}

${ }^{1}$ The SCMP (2014a) timeline is almost 8,500 words. We also consulted timelines in Mackey and Pan (2014) Cai (2016) and Ng (2016).

${ }^{2}$ Support3 received a message on 2 October warning her that something was going to happen the next day in Mong Kok. News reporters (News1\&2) were told that members of the Wo Shing Wo gang were among those involved in the Mong Kok attacks. Barrister3 intervened to stop a fistfight between an attacker and a group of student and later saw a magazine article describing the attacker as a member of Sun Yee On Triad (Barrister3). Psycologist1 noted that the attackers were receiving orders by cell phone. It should be noted the the attacks did not use firearms, in line with the stiff penalties for such usage in Hong Kong (see Lee, Broadhurst, and Beh, 2006; Barrister 3).

${ }^{3}$ News 1 added that the local population was not hostile to UM and many supported the protesters (News1). Indeed, a colleague of his pointed out that 'Mong Kok is famous for its street artists, so residents are used to people being in the streets' (News2). The owner of a nail salon also said that she never felt threatened by the protestors, although she did not support the occupation (Business1).

${ }^{4}$ The alterations to the minibus routes were regularly reported and updated. See HKitalk.Net (2014).

${ }^{5}$ He showed us photos of anti-UM posters. His minibus drivers displayed them inside their vehicles. He also filed an injunction against the Mong Kok protests on behalf of his Union. 